\title{
Social Skill Inventory-2 Del-Prette: expanding and updating psychometric properties
}

\author{
Inventário de Habilidades Sociais-2 Del-Prette: ampliando \\ e atualizando as propriedades psicométricas
}

Zilda Aparecida Pereira DEL PRETTE ${ }^{1}$ iD 0000-0002-0130-2911

Almir DEL PRETTE' ${ }^{\text {ID } 0000-0003-2051-1214 ~}$

Evandro Morais PEIXOTO² ID 0000-0003-1007-3433

\begin{abstract}
The aim of this research was to update the psychometric properties of the Del-Prette Social Skills Inventory-2, a measure of social performance in social interaction situations. The sample consisted of 4,250 participants of both sexes aged between 18 and 59 years old $(M=35.85 ; d f=11.33 ; 51.1 \%$ woman). Exploratory Structural Equation Modeling suggested the adequacy of the internal structure of the original version of the instrument, consisting of five factors: Assertive Conversation, Affective-Sexual Approach, Expression of positive sentiment, Self-Control/Coping, and Social Resourcefulness, all of them with good reliability indicators, alphas higher than 0.774 , and measurement invariance indicators across groups as a function of sex and different age ranges. The Partial Credit Model provided the item's and participant's parameters: difficulty level/theta and adjustment indices, which were adequate. The results suggest that the inventory is a suitable measure of social skills for professional and research purposes.
\end{abstract}

Keywords: Assertiveness; Interpersonal relations; Item response theory; Psychometrics; Sociability.

\section{Resumo}

O objetivo da presente pesquisa foi atualizar as propriedades psicométricas do Inventário de Habilidades Sociais Del-Prette, uma medida de desempenho sociais em situações de interação social. A amostra foi composta por 4.250 participantes de ambos os sexos com idade entre 18 e 59 anos ( $M=35,85 ; D P=11,33 ; 51,1 \%$ mulheres). A Análise de Equações

$\checkmark \nabla \nabla$

1 Universidade Federal de São Carlos, Departamento de Psicologia, Programa de Pós-Graduação em Psicologia. Alameda das Ameixeiras, 60, Parque Faber 1, 13561-358, São Carlos, SP, Brasil. Correspondence to: Z.A.P. DEL PRETTE. E-mail: <zdprette@ufscar.br>.

2 Universidade São Francisco, Departamento de Psicologia, Programa de Pós-Graduação em Psicologia. Campinas, SP, Brasil. Support: Conselho Nacional de Desenvolvimento Científico e Tecnológico (Process nº 306002/2017-5 and edital n 405658/2016-8).

$\boldsymbol{\nabla} \mathbf{v} \boldsymbol{\nabla}$

How to cite this article

Del Prette, Z. A. P., Del Prette, A., \& Peixoto, E. M. (2021). Social Skill Inventory-2 Del-Prette: expanding and updating psychometric properties. Estudos de Psicologia (Campinas), 38, e190124. https://doi.org/10.1590/1982-0275202138e190124 
Estruturais Exploratória indicou adequação da estrutura interna da versão original do instrumento, composta por cinco fatores: conversação assertiva, abordagem afetivo-sexual, expressão de sentimento positivo, autocontrole/enfrentamento e desenvoltura social. Todos obtiveram bons indicadores de precisão, alfas superiores a 0,774, e indicadores de invariância dos parâmetros da medida em função dos sexos e faixas etárias. O Modelo de Créditos Parciais forneceu os parâmetros dos itens e características dos participantes: niveis de dificuldades/theta e índices de ajuste, que se mostraram apropriados. Os resultados sugerem que o inventário é uma medida de habilidades sociais adequada para uso profissional e pesquisa.

Palavras-chave: Assertividade; Relações interpessoais; Teoria de resposta ao item; Psicometria; Sociabilidade.

The validity evidence and reliability indicators of the assessment instruments have been improved more and more in the last decades and at least two reasons seem to be the basis of this movement. The first one is the set of conceptual and methodological studies that, questioning aspects of the classical approach, have presented new proposals for procedures to assess the psychometric properties of the instruments. The second one is associated with the advancement of technology and information technology in enabling increasingly sophisticated analyzes.

In Psychology, the psychometric construction and updating of assessment instruments has gradually assimilated new trends. In the field of social skills, the first Brazilian assessment tool, the Del-Prette Social Skills Inventory (SSI-Del-Prette), was published 18 years ago (Z. Del Prette \& Del Prette, 2001) and has become a reference for research and clinical practice in this area. This instrument was part of the first set of tests assessed by the Sistema de Avaliação de Testes Psicológicos (Psychological Test Assessment System) at the Conselho Federal de Psicologia (Brazilian Federal Council of Psychology) which, soon after, in 2003, determined the updating of all instruments after 15 years of use (Conselho Federal de Psicologia, 2018). This is an important step, especially in the assessment of aspects susceptible to social and cultural changes that impact psychological variables, such as social skills (A. Del Prette \& Del Prette, 2017). This article is related to this need and describes the update of psychometric indicators of this instrument, in its new version called SSI2-Del-Prette.

In the presentation of the SSI2-Del-Prette with expanded and updated standards in Brazil, Z. Del Prette and Del Prette (2018) point out that research and clinical practices on skills started about 30 years ago in Brazil. These studies have accumulated evidence that a good repertoire of social skills is an important factor for harmonious interpersonal relationships, contributing to health, personal satisfaction, professional fulfillment, and quality of life. Conversely, deficits in social skills, usually associated with anxiety, undermine socially competent performance and are generally associated with problems in interpersonal relationships, a worse quality of life and various types of psychological disorders (Z. Del Prette \& Del Prette, 2019).

According to the conceptual basis of the SSI2-Del-Prette, social skills are "social behaviors valued in a given culture that increase the likelihood of favorable results for the individual, their group and the community, and can contribute to a socially competent performance in tasks related to interpersonal skills" (A. Del Prette \& Del Prette, 2017, p.24). Social skills are learned "naturally" in everyday interpersonal relationships, when personal and environmental conditions are favorable. When these are not favorable, there are deficits, which can be solved through educational and therapeutic programs. The assessment of resources and deficits in social skills is essential for planning effective programs (preventive or therapeutic).

This type of assessment of an individual's interpersonal performance generally focuses on different classes and subclasses of social skills. A. Del Prette and Del Prette (2017) present a portfolio with the subclasses of 10 general classes, which are important for anyone, even if relativized according to the stage of the life cycle: communication, civility, making and maintaining friendships, empathy, assertiveness, expressing solidarity, resolving conflicts and interpersonal problems, expressing affection and intimacy in sexual-affective 2 relationships, coordinating groups and speaking in public. The portfolio also includes an organization of 
relevant social skills in six important social roles that can be assumed by people throughout life: academic (students), educational (parents), educational (teachers), marital, professional, and caregivers.

It is a consensus, in the field of social skills, that the assessment must be multimodal (Z. Del Prette \& Del Prette, 2013), that is, based on different informants, indicators and instruments. As a starting point, this assessment generally includes self-report inventories that, in addition to their simplicity and ease of use, make it possible to compare the individual's resources and deficits with those of a normative reference sample.

In recent years, studies with the SSI-Del-Prette have covered a wide range of topics, with clinical and non-clinical samples and application to different areas of clinical performance of the psychologist, such as Health/Clinic, Forensic, Work/Organizational, Educational/School, Social/Community and Vocational/ Professional Guidance. It is an instrument adapted for other countries (Aguiar, Matias, Barham, Fontaine, \& Del Prette, 2018; Moran, Olaz, \& Del Prette, 2015) and which was the basis for the development of other instruments produced in Brazil, for example, for adolescents (A. Del Prette \& Del Prette , 2009; Romera-Leme, Valentini, Campos, Del Prette, \& Del Prette, 2017), for intergenerational relationships (Comodo, Del Prette, \& Del Prette 2017), for the assessment of anticipatory coping skills for alcohol and other drug use (Sá \& Del Prette, 2016) and for social skills of caring for elderly relatives (Queluz, Barham, Del Prette, Fontaine, \& Olaz, 2017), and psychiatric patients (Lima, 2019), in addition to a specific assertive social skills of women inserted in the labor market (Malcher, 2015).

Studies carried out with the SSI-Del-Prette contributed to the production of validity evidence based on correlation with external variables, such as the positive association, for example, between social skills and quality of life (Carneiro, Falcone, Clark, Del Prette, \& Del Prette 2007), psychological well-being (Guilland \& Monteiro, 2010; Queluz, Barham, \& Del Prette 2019), intelligence and performance at the university (Gomes \& Soares, 2013), in addition to others referred to in Z. Del Prette and Del Prette (2013). On the other hand, there were negative associations between deficits in social skills and indicators of problems such as, for example, burnout, anxiety and depression (Pereira-Lima, 2014), social anxiety (Angélico \& Loureiro, 2012), abuse of psychoactive substances (Sá \& Del Prette, 2016), among others. These studies allow to characterize social skills as protective factors and deficits in this repertoire as risk factors. Such evidence justifies the promotion of social skills within conditions favorable to human development and quality of life, adding evidence of nomothetic validity to the items of the SSI2-Del-Prette.

The SSI-Del-Prette has been used in the assessment of many social skills programs, for example, with psychotic patients (Elkis et al., 2016) and with non-clinical population searching for work (Lopes, Gerolamo, Del Prette, Musetti, \& Del Prette, 2015; Pereira-Guizzo, Del Prette, \& Del Prette, 2019). The studies added validity evidences and reliability indicators to the instrument, whose items were kept almost entirely in SSI2Del-Prette.

The construction of the SSI-Del-Prette was primarily concerned with the social skills of young adults, especially university students, and was validated for a normative sample aged 18 to 25 years, with satisfactory validity evidences and reliability indicators. However, over the past 15 years, the SSI-Del-Prette was also being used (especially its computerized version) with people older than the normative sample, which evidenced the need to expand its applicability to a broader age range of adults.

In order to meet this need, considering the history of the instrument and the accumulation of studies to which it has been associated, the researchers of this paper have sought to organize, in recent years, a database aiming at its standardization for adults above the original age group. The present study reports the psychometric update carried out for the population aged 18 to 59 years, based on the original items. Specifically, new evidence of validity is presented based on the internal structure, evidence of precision and properties of items, such as difficulty and adjustment indices, to the measurement model. For this purpose, different procedures were used, some of which were carried out in the Classic Test Theory and others in the modern theory of tests such as the Item Response Theory, which will be specified in the method section. 


\section{Method}

\section{Participants}

This update was based on a database collected from 2008 to 2012, with 4,250 individuals from various regions of Brazil, although predominantly in the Southeast region, in the proportions: Center-West $=6.4 \%$; Northeast $=10.2 \%$; North $=1.3$; Southeast $=70.8$; South $=10.7 \%$. The sample was stratified according to the sex/age distribution of the 2010 Southeast Region Census. Thus, the survey included participants of both sexes, $51.1 \%$ women and $49.9 \%$ men, divided into two broader ranges: from 18 to 38 years old, with 2,541 individuals (59.8\%), and from 39 to 59 years old with 1,709 individuals (40.2\%), thus remaining similar to the census distribution (60.3\% and $39.96 \%$ respectively).

Data on education and socioeconomic status were only obtained from part of the sample, which covers all ages, but predominantly up to 40 years old (part of these subjects were excluded from the sample in the process of random selection aiming at stratification by age and sex). Considering the subsample with some type of formal education $(n=1,807)$, the following distribution was found: Elementary School $=1.5 \%$; High School $=11.3 \%$, Incomplete Higher Education $=70.2 \%$, Complete Higher Education $=13.9 \%$, Postgraduate (latu senso) $=3.0 \%$.

Data on the socioeconomic level (Associação Brasileira de Empresas de Pesquisa, 2012), were also obtained from part of the sample ( $n=616$ subjects), whose distribution was as follows: Class $E=0.2 \%$; Class $\mathrm{D}=5.7 \%$; Class C = 26.0\%; Class B2 = 20.1\%; Class B1 = 22.6\%; Class A2 = 18.3\%; Class A1 = 7.1\%. In this case, there was a concentration of intermediate levels B1, B2 and C, while the Brazilian population has a greater distribution at the lower levels ( $C, D$ and $E$ ). Although these data are not stratified, they were used in the analysis of the relationship of these two variables with the social skills scores (below).

\section{Instrument}

Social Skills Inventory (SSI-Del-Prette) - (Z. Del Prette \& Del Prette, 2001): The SSI-Del-Prette is a selfreport instrument, composed of 38 items that allow the assessment of pertinent and relevant social skills for different situations of social interaction (work, school, family, daily life). Each item describes a situation of social interaction and a possible reaction to it. In the instructions, the respondent is asked to estimate the frequency with which he would react as described in each item, considering the total number of times he has found himself in that situation. The SSI-Del-Prette Answer Sheet contains a header for the characterization of the respondent and columns corresponding to a Likert-type Scale, with five points ranging from never or rarely (zero) to always or almost always (four). To minimize the effect of "social desirability", 12 of the 30 retained items were written with negative phrasing or meaning, that is, the suggested reaction is indicative of lack of skill. This is the case, for example, of item 13: At my job or at my school, if someone pays me a compliment, I feel embarrassed without knowing what to say. In these "negative" items for computing scores, an inversion of the score was made. Studies of psychometric properties have indicated an internal structure composed of five factors: Coping with risk, Self-affirmation in the expression of positive affection, Conversation and social resourcefulness, Self-exposure to strangers or new situations, Self-control of aggression in aversive situations, all with good indicators of reliability (Cronbach's alpha between 0.74 and 0.96 ).

\section{Procedures}

The face-to-face data collection was performed according to the instructions in the Manual ( $Z$. Del Prette \& Del Prette, 2001), with the respondent filling out the questionnaire in the presence of one of the 
staff members, in small groups, preceded by reading the instructions and certifying that they were correctly understood. The online collection was done in a similar way but at the time of verification, the staff member (a psychologist, registered in the Federal Council of Psychology and in the Publisher's web system) uploaded the data to the web page that immediately generated the graphs of the results and a report, and requested authorization to use this data in this study. When the respondent authorized the use of his or her data, the system suppressed the respondent's name and inserted their responses in a database.

The research project was approved by the Research Ethics Committee of the university where it was carried out, Universidade Federal de São Carlos (UFSCar, Federal University of São Carlos) protocol n 360/210. Therefore, the participation in this research was conditioned to the participants' formal consent by signing the consent form.

\section{Data analysis}

To assess the internal structure of the SSI-Del-Prette, the Exploratory Structural Equation Modeling (ESEM) method was used with the Weighted Least Squares Mean and Variance-adjusted (WLSMV) estimation method, based, therefore, on a polychoric correlation matrix. In this procedure, for estimating the internal structure, the number of factors is established based on previous, theoretical, or empirical information (Tomás, Marsh, González-Romá, Valls, \& Nagengast, 2014), for that, the researchers of this study used the psychometric information of the original version of the SSI (Z. Del Prette \& Del Prette, 2001). One of the main advantages of the ESEM method corresponds to the fact that, even though it is an exploratory method, it allows the performance of multigroup analysis and, therefore, the verification of invariance indicators of the measurement models. In this research, the invariance indicators were assessed according to the participants' sex and age groups. In the assessment of the adjustment indices, the values commonly observed in the literature were considered: WLSMV $\lambda^{2} / d f<5$, Root Mean Square Error Aproximation (RMSEA) $<0.08$, Comparative Fit Index (CFI) and Tucker Lewis Index (TLI) $>0.90$ as adequate, and WLSMV $\lambda^{2} / d f<3$, RMSEA < 0.06, CFI and TLI > 0.95 as good (L. Muthén \& Muthén, 2017). To assess the indicators of reliability, Cronbach's Alpha indices obtained with the individual factors and the total scale were used, with reference values above 0.7 . These analyzes were performed with the support of the Mplus v7.4 and Factor v10.8.04 software, respectively.

To estimate the item properties and the characteristics of the participants, the Rasch-Masters Partial Credit Model (PCM) (Wright \& Masters, 1982), was used, with the Maximum Likelihood estimation method. Thus, difficulty (b) and item adjustment (Infit, Outfit) indices, intensity levels in the construct (theta) presented by the participants, as well as correlation indices between item-theta were verified. According to Linacre (2015), the Infit and Outfit indices can vary from zero to infinity, with values close to one indicating a good fit, considering values between 0.5 and 1.5 as adequate. The probability curves of the response categories were also inspected, in this case, the tested hypothesis was whether the response categories of the items that make up the SSI-Del-Prette had been graded, through a statistical procedure, according to the previously established theoretical perspective. All analyzes concerning the PCM were carried out using the Winsteps Statistical Software (version 3.70.0) (Linacre, 2015).

\section{Results}

Initially, the five-factor model of the original version of the SSI-Del-Prette was tested (Z. Del Prette \& Del Prette, 2001). The results, based on the ESEM, indicated adjustment indices that could be classified as good $-\lambda^{2}=1823,539 ; d f=295 ; \lambda^{2} / d f=4.52, p<0.001 ; C F I=0.966 ;$ TLI = 0.950; RMSEA = 0.037 (I.C. 
$90 \%=0.033-0.037)$. This factorial model is shown in Table 1, together with the standardized factorial loads of the items (only above 0.3 ) in each of the factors, the correlations between factors, and the internal consistency index of the factors and the total scale.

Table 1

Factorial structure of the SSI2-Del-Prette for the general sample, aged 18 to 59, and indicators of internal consistency

\begin{tabular}{|c|c|c|c|c|c|c|}
\hline \multicolumn{2}{|l|}{ SSI2-Del-Prette - Items } & F1 & F2 & F3 & F4 & F5 \\
\hline \multicolumn{2}{|l|}{ 08. Participating in conversation } & 0.712 & & & & \\
\hline \multicolumn{2}{|l|}{ 17. Ending a conversation } & 0.694 & & & & \\
\hline \multicolumn{2}{|l|}{ 18. Dealing with parental criticism } & 0.675 & & & & \\
\hline \multicolumn{2}{|l|}{ 13. Responding to a compliment } & 0.669 & & & & \\
\hline \multicolumn{2}{|l|}{ 24. Ending a telephone conversation } & 0.573 & & & & \\
\hline \multicolumn{2}{|l|}{ 33. Negotiating the use of condom } & 0.545 & & & & \\
\hline \multicolumn{2}{|l|}{ 36. Maintaining a conversation } & 0.521 & & & & \\
\hline \multicolumn{2}{|l|}{ 19. Addressing authority figures } & 0.474 & & & & 0.298 \\
\hline \multicolumn{2}{|l|}{ 26. Asking strangers for favors } & 0.455 & & & & \\
\hline \multicolumn{2}{|l|}{ 23. Asking questions to strangers } & 0.451 & & & & \\
\hline \multicolumn{2}{|l|}{ 22. Refusing abusive requests } & 0.434 & & & & \\
\hline \multicolumn{2}{|c|}{ 09. Speaking to an unknown audience } & 0.407 & & & & 0.336 \\
\hline \multicolumn{2}{|l|}{ 02. Requesting a change of conduct } & 0.393 & & & & \\
\hline \multicolumn{2}{|l|}{ 12. Approaching sexual intercourse } & & 0.754 & & & \\
\hline \multicolumn{2}{|c|}{ 07. Introducing yourself to another person } & & 0.563 & & & \\
\hline \multicolumn{2}{|c|}{ 20. Declaring romantic feelings } & & 0.442 & & & \\
\hline \multicolumn{2}{|c|}{ 01. Maintaining a conversation with strangers } & & & & & 0.326 \\
\hline \multicolumn{2}{|c|}{ 28. Praising family members } & & & 0.808 & & \\
\hline \multicolumn{2}{|l|}{ 10. Expressing positive feelings } & & & 0.625 & & \\
\hline \multicolumn{2}{|l|}{ 35. Expressing positive feelings } & & & 0.587 & & \\
\hline \multicolumn{2}{|l|}{ 03. Thanking for compliments } & & & 0.585 & & \\
\hline \multicolumn{2}{|l|}{ 06. Praising others } & & & 0.539 & & \\
\hline \multicolumn{2}{|l|}{ 25. Dealing with fair criticism } & & & 0.509 & & \\
\hline \multirow{2}{*}{\multicolumn{2}{|c|}{ 31. Greeting strangers }} & & & 0.449 & & 0.385 \\
\hline & & & & 0.373 & & 0.431 \\
\hline \multicolumn{2}{|l|}{ 30. Defending others in a group } & & & & 0.297 & \\
\hline 15. Dealing with unfair criticism & & & & & 0.672 & \\
\hline 16. Disagreeing in a group of aca & ces & & & & 0.660 & \\
\hline 27. Expressing displeasure to frier & & & & & 0.384 & \\
\hline 11. Disagreeing with authority fig & & & & & 0.353 & 0.332 \\
\hline & Cronbach's alpha & 0.934 & 0.774 & 0.894 & 0.840 & 0.840 \\
\hline & Explained variance & 20.8 & 6.2 & 16.2 & 6.9 & 9.7 \\
\hline Correlation between factors & & & & & & \\
\hline F1 - Assertive conversation & & - & & & & \\
\hline F2 - Affective-sexual approach & & 0.153 & - & & & \\
\hline F3 - Expression of positive feeling & & 0.139 & 0.211 & - & & \\
\hline F4 - Self-control/Coping & & 0.087 & 0.348 & 0.336 & - & \\
\hline F5 - Social resourcefulness & & 0.158 & 0.217 & 0.333 & 0.081 & - \\
\hline
\end{tabular}

Note: SSI2-Del-Prette: Social Skills Inventory.

About the factorial structure, a grouping of items was obtained, equivalent to the theoretical proposal, that supported the development and studies carried out with SSI-Del-Prette: F1- Assertive conversation; F2- Affective-sexual approach; F3- Expression of positive feeling; F4- Self-control/Coping; F5- Social resourcefulness. In this sense, the factors constitute classes of social skills, defined in behavioral-situational terms, that is, sets of behaviors required for certain situations and with a similar function before them. In the case of Factor 5 , composed of items from other factors, it is a class of response that permeates different skills and, therefore, more generalizable to different contexts and situations.

The correlation indices between the factors ranged from 0.087 (F1 and F4) to 0.348 (F2 and F4), and it is possible to imply a low overlap between them regarding the theoretical contents addressed by the factors that make up the measurement model. Regarding the internal consistency indices and Cronbach's 6 alpha coefficients, all factors, as well as the total scale, presented values equal to or greater than 0.77 , which 
indicates good levels of reliability of the factors. The percentage of variance explained by the five factors was $59.8 \%$, indicating the structure's ability to retrieve the information from the variables inserted in the model.

Based on these indicators, the factorial model's invariance was tested according to the participants' sex and age group (between the18-39 and the 40-59 sample). The results are shown in Table 3, based on the adjustment indices produced by the ESEM-Multigroups. In the assessment of the factorial models for the groups performed separately, the results indicate the adequacy of the model for all cases. The assessment of the configural and scalar invariance for each of the comparisons, between sex and age group, is shown in Table 2.

Table 2

Adjustment indices of ESEM-Multigroups for the SSI2-Del-Prette

\begin{tabular}{|c|c|c|c|c|c|c|}
\hline Group / model & Parameters & WLSMV $\lambda^{2}(d f)$ & $p$ & $\mathrm{CFI}$ & TLI & RMESA (CI 90\%) \\
\hline \multicolumn{7}{|l|}{ Sex } \\
\hline $\begin{array}{l}\text { Female } \\
\text { Male } \\
\text { Configural } \\
\text { Scalar }\end{array}$ & $\begin{array}{l}257 \\
257 \\
514 \\
307\end{array}$ & $\begin{array}{r}1095.527(295) \\
872.350(295) \\
1959.187(590) \\
2556.437(797)\end{array}$ & $\begin{array}{l}<0.001 \\
<0.001 \\
<0.001 \\
<0.001\end{array}$ & $\begin{array}{l}0.967 \\
0.971 \\
0.969 \\
0.961\end{array}$ & $\begin{array}{l}0.952 \\
0.958 \\
0.955 \\
0.957\end{array}$ & $\begin{array}{l}0.036(0.034-0.038) \\
0.030(0.028-0.033) \\
0.033(0.031-0.035) \\
0.032(0.031-0.034)\end{array}$ \\
\hline $\begin{array}{l}\text { Age } \\
\quad>18<39 \\
>40<59 \\
\text { Configural } \\
\text { Scalar }\end{array}$ & $\begin{array}{l}257 \\
257 \\
514 \\
307\end{array}$ & $\begin{array}{r}946.987(295) \\
1191.343(295) \\
2125.774(590) \\
2685.673(797)\end{array}$ & $\begin{array}{l}<0.001 \\
<0.001 \\
<0.001 \\
<0.001\end{array}$ & $\begin{array}{l}0.965 \\
0.966 \\
0.966 \\
0.958\end{array}$ & $\begin{array}{l}0.949 \\
0.949 \\
0.946 \\
0.954\end{array}$ & $\begin{array}{l}0.036(0.033-0.039) \\
0.035(0.033-0.037) \\
0.035(0.033-0.037) \\
0.033(0.032-0.035)\end{array}$ \\
\hline
\end{tabular}

Note: $\star^{2}$ : Chi-square; $p$ : Statistical Significance.

CFI: Comparative Fit Index; CI: Confidence Interval; RMESA: Root Mean Square Error Aproximation; TLI: Tucker Lewis Index; WLSMV: Weighted Least Squares Mean and Variance-adjusted.

Table 3

Item properties estimated by the Partial Credit Model

\begin{tabular}{|c|c|c|c|c|c|c|c|c|c|c|c|c|c|c|}
\hline \multicolumn{5}{|c|}{ Assertive conversation } & \multicolumn{5}{|c|}{ Affective-sexual approach } & \multicolumn{5}{|c|}{ Expression of positive feeling } \\
\hline Items & $\mathrm{b}$ & Infit & Outfit & CORR. & Items & $b$ & Infit & Outfit & CORR. & Items & $\mathrm{b}$ & Infit & Outfit & CORR. \\
\hline 2 & 0.22 & 0.99 & 1.18 & 0.40 & 7 & 0.29 & 1.01 & 0.99 & 0.74 & 3 & -0.67 & 1.05 & 1.09 & 0.45 \\
\hline 8 & -0.33 & 1.04 & 0.94 & 0.61 & 12 & 0.69 & 0.94 & 0.90 & 0.75 & 6 & 0.40 & 0.92 & 0.96 & 0.61 \\
\hline 13 & -0.07 & 0.86 & 0.85 & 0.61 & 20 & -0.98 & 1.02 & 1.04 & 0.72 & 10 & 0.32 & 1.09 & 1.04 & 0.60 \\
\hline 17 & -0.14 & 0.86 & 0.84 & 0.61 & & & & & & 25 & 0.32 & 1.05 & 1.10 & 0.56 \\
\hline 18 & -0.42 & 0.95 & 0.93 & 0.58 & & & & & & 28 & -0.78 & 0.83 & 0.68 & 0.53 \\
\hline 19 & 0.26 & 0.87 & 0.89 & 0.56 & & & & & & 29 & 0.13 & 1.09 & 1.03 & 0.58 \\
\hline 22 & 0.19 & 1.13 & 1.17 & 0.50 & & & & & & 31 & 0.34 & 1.12 & 1.15 & 0.58 \\
\hline 23 & 0.24 & 1.03 & 1.09 & 0.52 & & & & & & 35 & -0.06 & 0.92 & 0.98 & 0.55 \\
\hline 24 & 0.05 & 0.97 & 0.97 & 0.57 & & & & & & & & & & \\
\hline 26 & 0.14 & 1.15 & 1.15 & 0.53 & & & & & & & & & & \\
\hline 33 & -0.30 & 1.64 & 1.56 & 0.50 & & & & & & & & & & \\
\hline 36 & 0.15 & 0.80 & 0.82 & 0.58 & & & & & & & & & & \\
\hline $\bar{M}$ & 0.00 & 1.02 & 1.03 & & & 0.00 & 0.99 & 0.98 & & & 0.00 & 1.01 & 1.00 & \\
\hline$S D$ & 0.23 & 0.21 & 0.20 & & & 0.71 & 0.04 & 0.06 & & & 0.44 & 0.10 & 0.13 & \\
\hline \multicolumn{5}{|c|}{ Self-control/Coping } & \multicolumn{5}{|c|}{ Social resourcefulness } & & & & & \\
\hline 11 & 0.33 & 1.00 & 1.00 & 0.62 & 1 & 0.72 & 1.03 & 1.02 & 0.56 & & & & & \\
\hline 15 & -0.21 & 1.12 & 1.08 & 0.62 & 9 & 0.26 & 1.41 & 1.36 & 0.52 & & & & & \\
\hline 16 & -0.11 & 0.89 & 0.87 & 0.65 & 11 & 0.53 & 0.97 & 0.98 & 0.58 & & & & & \\
\hline 27 & 0.36 & 1.07 & 1.06 & 0.61 & 19 & 0.27 & 1.13 & 1.14 & 0.53 & & & & & \\
\hline \multirow[t]{2}{*}{30} & -0.37 & 0.95 & 1.00 & 0.53 & 29 & -0.66 & 0.73 & 0.62 & 0.66 & & & & & \\
\hline & & & & & 31 & -0.47 & 1.07 & 1.08 & 0.52 & & & & & \\
\hline $\bar{M}$ & 0.00 & 1.00 & 1.00 & & & 0.00 & 1.01 & 0.98 & & & & & & \\
\hline$S D$ & 0.29 & 0.08 & 0.08 & & & 0.54 & 0.22 & 0.25 & & & & & & \\
\hline
\end{tabular}

Note: b: Difficulty; CORR.: Item-theta correlation.

M: Mean; SD: Standard Deviation. 
The results indicate the equivalence of the factorial composition between the groups (Configural Model) and the intercept of the items among the participants of the different groups (Scalar Model). In both cases, the difference in the CFI between the configural and scalar models is less than 0.01 (Wang, Chen, Dai, \& Richardson, 2018).

The next step was to obtain more information regarding the characteristics of the items through the PCM (Partial Credit Model, Rash Analysis). Table 3 presents the characteristics referring to the items, considering their respective factors, where the statistics (difficulty index), Infit/Outfit (adjustment of the response pattern of the items to the statistical model) and CORR (correlation between the item and the theta level estimated for the subject based on his or her response to all items) measures are highlighted.

Regarding the difficulty of the items, the data on b shows that the factors are composed of items that cover a restricted range at the theta level of the participants, between -0.42 (item 18) and 0.26 (item 19) for Factor 1; between -0.98 (item 20) and 0.69 (item 12) for Factor 2; between -0.78 (item 28) and 0.40 (item 6) for Factor 3; between -0.37 and 0.36 for Factor 4; and between -0.66 and 1.72 for Factor 5. These results indicate a small variation in difficulty and, therefore, which scale measures a limited range of the target latent trait. It is worth mentioning that this is common for instruments (or factors) composed of few items. However, this information should be taken into account in future versions of the instrument.

Regarding the infit adjustment index, the estimated mean values indicated the adequacy of these measures $(1.02 \pm 0.21 ; 0.99 \pm 0.04 ; 1.01 \pm 0.10 ; 1.00 \pm 0.08$; and $1.01 \pm 0.22$, respectively) and, therefore, the adequacy of the items to the response pattern expected by the model. Similar results are observed for the outfit indices, adequate mean values $(1.03 \pm 0.20 ; 0.98 \pm 0.05 ; 1.00 \pm 0.13 ; 1.00 \pm 0.08$; and $0.98 \pm$ 0.25 , for the respective factors), again item 33 presented a higher than expected result (1.56). Considering the values of the correlation indices between the items and theta scores, the results indicate correlations with magnitude levels between moderate and high, which indicate the ability of the items to recover the levels of intensity in the latent trait presented by the participants.

According to one of the objectives of this research, the characteristics of the participants were also assessed. The results are presented in Table 4, where a summary description is presented, including the following data: measure (level of intensity in the latent trait presented by the subject in the latent/factor variable) and adjustment indices (level of adjustment of the participants' responses to the response pattern expected by the model).

As shown in Table 4, the average values for Factors 1 (Assertive conversation), 2 (Affective-sexual approach), 3 (Expression of positive feeling), 4 (Self-control/Coping), and 5 (Social Resourcefulness) indicate that, in general, the participants presented latent trait levels in positive values on the

Table 4

Characteristics of the participants, estimated by the Partial Credit Model

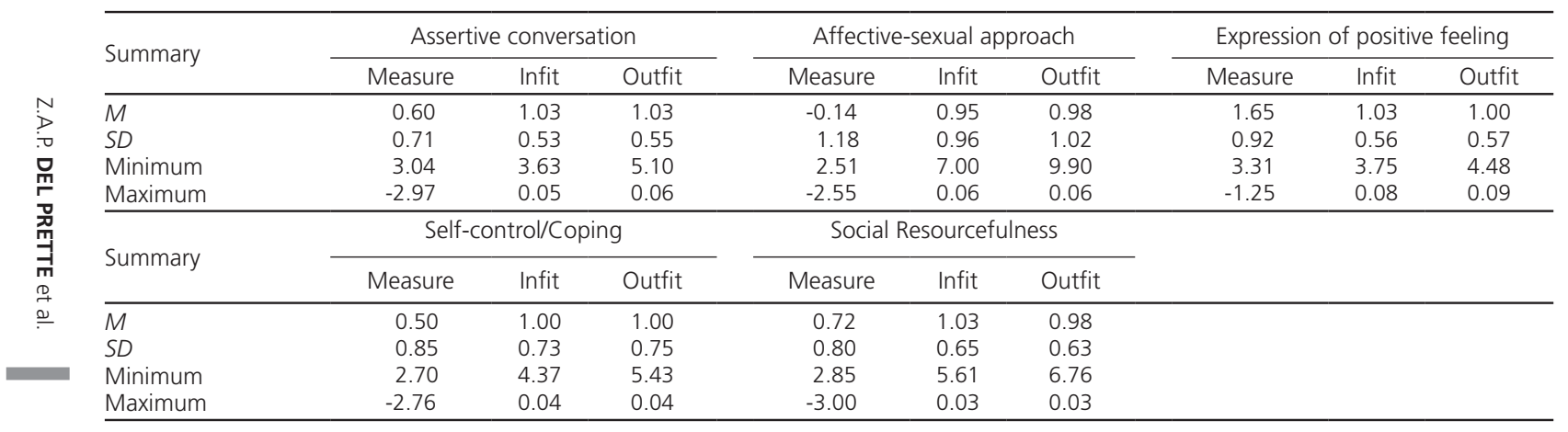

Note: M: Mean; SD: Standard Deviation. 
standardized scale, more specifically $(0.60 \pm 0.71 ; 1.65 \pm 0.92 ; 0.50 \pm 0.85$, and $0.72 \pm 0.80$, respectively). Such results indicate that, in general, the items that composed the factors were relatively easy to be endorsed by the participants who were part of the sample of this research, considering the anchoring procedure used, which "locked" the average of the items at zero within the standardized scale. Thus, it is observed that the latent trait level presented by the participants was higher than those presented by the difficulty indices of the items. However, for Factor 2, a different pattern was observed: in this specific case, the average of the latent trait level presented by the participants $(-0.14 \pm 1.18)$ was below the difficulty level for the items, which indicates that, in general, the items proved to be more difficult to endorse. Still in relation to the estimated latent trait levels, the minimum and maximum values indicate great variability of the subjects regarding the latent trait level (between -2.97 and 3.04 for Factor 1; between -2.55 and 2.51 for Factor 2; between -1.25 and 3.31 for Factor 3; between -2.76 and 2.70 for Factor 4; and between -3.00 and 2.85 for Factor 5).

Regarding the Infit and Outfit adjustment indices, the average values obtained in all factors indicate the adequacy of the responses of the participants to what was expected by the model. The minimum and maximum statistics do not concern this case (since they report lower and higher values than expected), given the magnitude of the sample and, therefore, the greater probability of the existence of people with an unexpected response pattern.

\section{Discussion}

The main objective of this research was the psychometric update of the SSI-Del-Prette, for the population from 18 to 59 years of age. To this end, new validity evidence was produced based on the internal structure and reliability for the instrument. The properties of the items were also verified, such as difficulty and adjustment indices, as well as the characteristics of the participants, such as levels of intensity in the latent traits assessed by the instrument.

In view of the scope of the objectives, different statistical procedures were employed. Using the ESEM method, an equivalence of the grouping of items with the theoretical proposal (Z. Del Prette \& Del Prette, 2013; A. Del Prette \& Del Prette, 2017) was observed, as well as the empirical results observed in the first estimation studies of the internal structure of the SSI-Del-Prette (Del Prette, Del Prette, \& Barreto, 1998) with a sample of individuals between 18 and 25 years old, based on a Principal Component Analysis with Varimax rotation, established, therefore, on Pearson correlation matrices (Tabachnick \& Fidell, 2012). Such results indicate the stability of the item grouping defended here, since it had replicability, even with different statistical procedures.

From the structure obtained, the first factor was called Assertive Conversation and brought together items related to self-assertion skills in situations which may require initiating and maintaining conversation, speaking in public, expressing displeasure, and asking for behavior change. The second factor, called Affective-Sexual Approach, grouped items related to affective-sexual expression skills, including initiating and maintaining conversation with new people, introducing oneself, declaring romantic feelings, and approaching sexual intercourse. The third factor, Expression of Positive Feeling, brought together items associated with skills to deal with the demands for expressing positive affection towards family members and others, including giving and taking compliments, expressing affection and love, talking to strangers, and even dealing with criticism and defending others as a group. The fourth factor, Self-control/Coping, was composed of items that described the skills to deal with situations that demand self-control and assertive coping, that is, with the potential risk of undesirable reactions by the interlocutor (possibility of rejection, objection, or opposition), such as reacting to unfair criticism, expressing displeasure, disagreeing in a group of interlocutors (possibility of rejection, objection, or opposition), disagreeing in a group of acquaintances or 
people of authority, defending someone who is being criticized. Finally, the fifth and last factor, called Social Resourcefulness, brought together items related to a set of skills that express disinhibition and social skills in the face of interactive demands in general, in response to demands for interaction with acquaintances, strangers, people with group authority, and self-assertion, which justifies its overlap with other factors.

As for the factorial loads presented by the items, it is possible to infer that they adequately represented the target constructs, since they presented values equal to or higher than the cutoff point commonly used in the specialized literature, of 0.30 (Tabachnick \& Fidell, 2012). Regarding the number of items in each of the estimated factors, it can be said that these are adequate for the assessment of the constructs in question. There is an expectation that the minimum number of items to represent a factor can vary between three and five, depending on the construct. Finally, the good indicators of precision presented by the factors and the total scale are highlighted, with Cronbach's alpha coefficients higher than 0.8 , which support the evidence of accuracy of the instrument (American Educational Research Association, American Psychology Association, \& National Council on Measurement in Education, 2014).

Still in relation to the factorial structure, it is observed that Factor 5 has five items, initially developed for the assessment of other factors, thus presenting cross factorial loads. However, when these loads are grouped in this factor, they show a different theoretical understanding from those assessed in their original factors, maintaining a theoretical homogeneity when grouped in Factor 5. This understanding is supported, empirically, by the low magnitude correlations observed between the factors of the inventory, as well as the structure observed in the first version of the instrument (Z. Del Prette \& Del Prette, 2001), which led the authors to choose to maintain the items and propose the assessment of factors to be done separately, including in the development of interpretative standards (Z. Del Prette \& Del Prette, 2018). This decision also supported the use of PCM, a one-dimensional Item Response Theory model in which the factors were treated independently. According to Linacre (2015), although most psychological constructs are understood as multidimensional, keeping an oblique relationship between the different dimensions, commonly, the instruments for assessing these constructs are developed with the specific purpose of assessing each of these dimensions in an independent way, taking the measures as "one-dimensional". For the author, even in these cases, multidimensionality always exists, to a lesser or greater degree, given that there will always be influences from other aspects not covered by the target latent construct in the response to a set of items.

Another important aspect regarding the internal structure of the SSI2-Del-Prette concerns the invariance of the assessed parameters (configural and scalar model) between the different groups, according to the sex and age of the participants, with results that guarantee the equivalence of the factorial structure and of the intercept values of the items for the participants of the different groups. According to Wang et al. (2018), the parameter invariance indicates that the observable variables of an instrument are related to latent variables in an equivalent manner between groups. In this sense, such evidence should be considered as a requirement for future comparisons between these groups based on the scores obtained with the instrument, ensuring that possible differences between the groups would be linked to real differences in the constructs and not to measurement errors associated with the instrument. Obtaining such evidence meets one of the main objectives of this study, which was to expand the instrument's psychometric properties and, especially, to verify evidences of validity based on the internal structure (American Educational Research Association, American Psychology Association \& National Council on Measurement in Education, 2014) for a sample of individuals over 25 years old. It can be said that the objectives were satisfactorily achieved.

Based on the indicators produced through the PCM, it was possible to verify the properties of the items and the difficulty indices that demonstrated the adequacy of the scale to assess people with low and close to average social skills. These findings are in line with the motivations that inspired the construction of the SSI-Del-Prette (Del Prette et al., 1998; A. Del Prette \& Del Prette, 2001; Z. Del Prette \& Del Prette, 2013): the need for an instrument capable of providing information for the development of preventive and therapeutic 
actions in the field of social skills. In this sense, the SSI2-Del-Prette has a good ability to identify, in a precise way, people with low and medium levels in different spheres of social skills, justifying interventions aimed at overcoming these difficulties.

This greater concentration of efforts to recognize people with lower levels in the different aspects of social skills explains the greater variability of the latent traits presented by the participants, when compared to the variability presented by the indices of difficulty of the items in the different factors that make up the SSI-Del- Prette. In this sense, the fragility of the scale to assess people with high levels of social skills should be highlighted (although the correlation values between item-theta indicate the ability of the items to adequately recover the participants' theta values) and such information must be taken into account by the researchers or professionals, as well as in the development of new versions of the instrument, considering the possibility of building new items that allow researchers to identify higher levels of the theta scale.

Still regarding the relationship between the difficulty of the items and the level of intensity in the construct presented by the sample accessed, it is highlighted that, on average, only for the Affective-Sexual Approach factor, the level of intensity in the trait was below the level of difficulty of the items, which suggests that the participants found it more difficult to endorse the contents of the items of this factor. This point shows greater variability among people, in general, to deal with affective-sexual demands, to which campaigns on sexual harassment and possibly some culturally constructed modesty in relation to themes in this area may be a contributing factor. In any case, it is an issue that could be the subject of research focused on variables potentially related to this theme, such as age, education, sex, socioeconomic level, and even cultural differences between Brazilian regions.

Another characteristic of the items that make up the SSI-Del-Prette was that the good infit/outfit indices presented, all within the response pattern expected by the model, with the exception of item 33, demonstrate the ability to be predicted according to the latent trait level of the respondent. In the case of item 33 (Negotiating the use of condom) of the Assertive Conversation factor, with an index outside the expected range, it can be concluded that people with low levels of assertive conversion could accept negotiating the use of condom, or vice versa. This result has not been documented in the literature, but it is important to recognize that negotiating the use of condom during sex depends on a combination of factors. Among which stand out the greater or lesser acceptance and confidence in information about the risks of sexually transmitted diseases; the personal situation of sexual deprivation, the degree of affective involvement and the power of convincing the other person. Considering that social skills are situational and specific (A. Del Prette \& Del Prette, 2019), health care and prevention campaigns could lead some people to develop the ability to occasionally negotiate condom use, even if they fail in the face of other demands for assertiveness.

Finally, the curves related to the item response categories were inspected. The results indicated the adequacy in the graduation of response categories and, therefore, an increasing monotomic relationship between latent trait levels and the probability of endorsement of the Likert scale categories used in the instrument, which indicates the adequacy of the response system used in this study. Thus, one can infer, from the set of results obtained with the PCM, the adequacy of the properties of the items that compose the different factors of the SSI-Del-Prette.

\section{Final Considerations}

In summary, it can be said that the characteristics of the SSI2-Del-Prette add to the previous evidence supporting its use, both by the professional and the researcher. In its current format, SSI2-Del-Prette can be considered a brief scale, which facilitates its use in clinical practice and research. Its use can be recommended both for screening purposes and for pre- and post-educational, or therapeutic assessments. In the research, 
the results suggest that it is possible to continue, now with security and expanding of the sample, the studies that had already been previously done. In particular, the importance of the instrument for longitudinal studies and for cross-sectional comparisons with adult populations of different age groups can be highlighted.

The set of studies already carried out with the SSI-Del-Prette in Brazil allows researchers to make up a nomological network of relationships already established between the repertoire of social skills and their positive impact on quality of life, health and well-being factors, while attesting to the negative impact of deficits in this area and their association with different disorders or problems, both physical and psychological. Additionally, the studies reinforce assumptions such as sex differences and the impact of culture or subculture on social skills patterns that are valued, tolerated, or disapproved in different contexts and moments of human development.

\section{Contributors}

Z. A. P. DEL PRETT was responsible for the research design, analysis interpretation and manuscript writing. A. DEL PRETTE contributed to the literature review, research design, analysis interpretation and manuscript writing. E. M. PEIXOTO, was responsible for the data analysis, interpretetion and the manuscript writing.

\section{References}

Aguiar, J. C. S., Matias, M., Barham, E. J., Fontaine, A. M. G. V., \& Del Prette, Z. A. P. (2018). An initial study of the internal validity of the portuguese adaptation of the marital social-skills inventory. Estudos de Psicologia (Campinas), 35(3), 275-285. https://doi.org/10.1590/1982-02752018000300006

American Educational Research Association, American Psychology Association, \& National Council on Measurement in Education. (2014). Standards for educational and psychological testing. Washington: American Educational Research Association.

Angélico, A. P., \& Loureiro, S. R. (2012). Utilização do inventário de habilidades sociais no diagnóstico do transtorno de ansiedade social. Psicologia: Reflexão e Crítica, 25, 467-476. https://doi.org/10.1590/S0102-79722012000300006

Associação Brasileira de Empresas de Pesquisa. (2012). Critério de classificação econômica Brasil. São Paulo: Autor. Disponível em http://www.abep.org/Servicos/Download.aspx?id=03

Carneiro, R. S., Falcone, E., Clark, C., Del Prette, Z. A. P., \& Del Prette, A. (2007). Qualidade de vida, apoio social e depressão em idosos: relação com habilidades sociais. Psicologia: Reflexão e Crítica, 20(2), 229-237. https://doi:10.1590/ s0102-79722007000200008

Comodo, C. N., Del Prette, A., \& Del Prette, Z. A. P. (2017). Intergeracionalidade das habilidades sociais entre pais e filhos adolescentes. Psicologia: Teoria e Pesquisa, 33, 1-9. https://doi.org/10.1590/0102.3772e33311

Conselho Federal de Psicologia. (2018). Resolução $n^{\circ}$ 09, de 25 de abril de 2018. Estabelece diretrizes para a realização de Avaliação Psicológica no exercício profissional da psicóloga e do psicólogo, regulamenta o Sistema de Avaliação de Testes Psicológicos - SATEPSI e revoga as Resoluções $n^{\circ}$ 002/2003, $n^{\circ}$ 006/2004 e $n^{\circ} 005 / 2012$ e Notas Técnicas $n^{\circ}$ 01/2017 e 02/2017. Brasília: Autor. Disponível em https://site.cfp.org.br/wp-content/uploads/2018/04/ Resolu\%C3\%A7\%C3\%A3o-CFP-n\%C2\%BA-09-2018-com-anexo.pdf

Del Prette, A., \& Del Prette, Z. A. P. (2001) Psicologia das relações interpessoais: vivências para o trabalho em grupo. Petrópolis: Editora Vozes.

Del Prette, A., \& Del Prette, Z. A. P. (2009). Inventário de Habilidades Sociais para Adolescentes (IHSA-Del-Prette): manual de aplicação, apuração e interpretação. São Paulo: Casa do Psicólogo.

Del Prette, A., \& Del Prette, Z. A. P. (2017). Competência social e habilidades sociais: manual teórico-prático. Petrópolis: Editora Vozes. https://doi.org/10.7476/9786580216161

Del Prette, Z. A. P., \& Del Prette, A. (2001). Inventario de Habilidades Sociais (IHS-Del-Prette): manual de aplicação, apuração e interpretação. São Paulo: Casa do Psicólogo.

Del Prette, Z. A. P., \& Del Prette, A. (2013). Social Skills Inventory (SSI-Del-Prette): characteristics and studies in Brazil. In F. L. Osório (Org.), Social anxiety disorders: from theory to practice (pp.49-62). New York: Nova Science Publishers. 
Del Prette, Z. A. P., \& Del Prette, A. (2018). Inventário de Habilidades Sociais (IHS2-Del-Prette): manual de aplicação, apuração. São Paulo: Pearson.

Del Prette, Z. A. P., \& Del Prette, A. (2019). Studies on social skills and social competence in Brazil: a history in construction. In S. H. Koller (Org.), Psychology in Brazil: scientists making a difference. Cham: Springer. https://doi.org/10.1007/97 8-3-030-11336-0_4

Del Prette, Z. A. P., Del Prette, A., \& Barreto, M. C. M. (1998). Análise de um Inventário de Habilidades Sociais (IHS-DelPrette) em uma amostra de universitários. Psicologia: Teoria e Pesquisa, 14(3), 219-228.

Elkis, H., Scemes, S., Savoia, M. G., Del Prette, Z. A. P., Mestriner, P., \& Silva, A. R. (2016). Social dysfunction and skills in schizophrenia: relationship with treatment response and severity of psychopathology. Archives of Clinical Psychiatry, 43(5), 107-111. https://doi.org/10.1590/0101-60830000000095

Gomes, G., \& Soares, A. B. (2013). Inteligência, habilidades sociais e expectativas acadêmicas no desempenho de estudantes universitários. Psicologia: Reflexão e Crítica, 26(4), 780-789. https://doi.org/10.1590/S0102-79722013000400019

Guilland, R., \& Monteiro, J. K. (2010). Jovem em situação de desemprego: habilidades sociais e bem-estar psicológico. Psicologia: Teoria e Prática, 12(3), 149-163. https://doi.org/10.4013/ctc.2010.31.05

Lima, D. C. (2019). Desenvolvimento de um instrumento de habilidades sociais para familiares cuidadores de pacientes psiquiátricos (Dissertação de mestrado não-publicada). Universidade Federal de São Carlos.

Linacre, J. M. (2015). A user's guide to winsteps ministep: rasch-model computer programs. Abingdon: Winsteps. Retrieved from http://www.winsteps.com

Lopes, D. C., Gerolamo, M. C., Del Prette, Z. A. P., Musetti, M. A., \& Del Prette, A. (2015). Social skills: a key factor of engineering students to develop interpersonal skills. International Journal of Engineering Education, 31(1), $405-413$.

Malcher, C. (2015). Assertividade: escala multimodal e caracterização do repertório de mulheres inseridas no mercado de trabalho (Tese de doutorado não-publicada). Universidade Federal de São Carlos.

Moran, V. E., Olaz, F. O., \& Del Prette, Z. A. P. (2015). Social Skills Questionnaire for Argentinean College Students (SSQ-U): development and validation. The Spanish Journal of Psycology, 18(95), 1-11. https://doi.org/10.1017/sjp.2015.92

Muthén, L. K., \& Muthén, B. O. (2017). Mplus user's guide. Los Angeles: Author. Retreived from https://www.statmodel. com/download/usersguide/MplusUserGuideVer_8.pdf

Pereira-Guizzo, C. S., Del Prette, A., \& Del Prette, Z. A. P. (2019). Analysis of needs and processes: social skills program for unemployed people with disabilities. Psico-USF, 24(3), 463-474. https://doi.org/10.1590/1413-82712019240305

Pereira-Lima, K. (2014). Associações e comparações entre burnout, ansiedade, depressão e habilidades sociais de residentes médicos de diferentes áreas (Dissertação de mestrado não-publicada). Universidade de São Paulo.

Queluz, F. N. F. T., Barham, E. J., \& Del Prette Z. A. P. (2019). The relationship between social skills and psychosocial adjustment among those who care for older adults. Paidéia, 29, e2917. https://doi.org/10.1017/sjp.2017.29

Queluz, F. N. F. R., Barham, E. J., Del Prette, Z. A. P., Fontaine, A. M. F. V., \& Olaz, F. (2017). Inventário de Habilidades Sociais para Cuidadores de Idosos (IHS-CI): evidências de validade. Avaliação Psicológica, 6(1), 78-86. https://doi. org/10.15689/ap.2017.1601.09

Romera-Leme, V. B., Valentini, F., Campos, J. R., Del Prette, Z. A. P., \& Del Prette, A. (2017). Psychometric properties of the brief version of the Social Skills Inventory for adolescents. The Spanish Journal of Psychology, 20, e36. https:// doi.org/10.1017/sjp.2017.29

Sá, L. G., \& Del Prette, Z. A. P. (2016). habilidades de enfrentamento antecipatório para abstinência de substâncias: construção de um novo instrumento de medida. Avances en Psicologia Latinoamericana, 34, 351-363. https://doi. org/10.12804/apl34.2.2016.09

Tabachnick, B. G., \& Fidell, L. S. (2012). Using multivariate statistics. New Jersey: Person.

Tomás, I., Marsh, H. W., González-Romá, V., Valls, V., \& Nagengast, M. (2014). Testing measurement invariance across Spanish and English versions of the physical self-description questionnaire: an application of exploratory structural equation modeling. Journal of Sport \& Exercise Psychology, 36, 179-188. https://doi.org/10.1123/jsep.2013-0070

Wang, S., Chen, C. C., Dai, C. L., \& Richardson, G. B. (2018). A call for, and beginner's guide to, measurement invariance testing in evolutionary psychology. Evolutionary Psychological Science, 4, 166-178. https://doi.org/10.1007/s40806-0 17-0125-5

Wright, B. D., \& Masters, G. N. (1982). Rating scale analysis. Chicago: Mesa Press.

Received: September 5, 2019

Final version: March 4, 2020

Approved: June 3, 2020 